\title{
Yield of different rice cultivars at two levels of soil salinity under seawater intrusion in West Java, Indonesia
}

\author{
NUNING A. SUBEKTI ${ }^{1, \bullet}$, HASIL SEMBIRING ${ }^{2}$, ERYTHRINA $^{3}$, DEDI NUGRAHA ${ }^{1}$, BHAKTI PRIATMOJO ${ }^{1}$, \\ NAFISAH ${ }^{4}$ \\ ${ }^{1}$ Indonesian Center for Food Crops Research and Development. Jl. Merdeka No. 147, Bogor 16111, West Java, Indonesia. \\ Tel./fax.: +62-271-663375, `email: argosubekti@gmail.com \\ ${ }^{2}$ International Rice Research Institute, Indonesia Office. Jl. Merdeka No. 147, Bogor 16111, West Java, Indonesia \\ ${ }^{3}$ Indonesian Center for Agricultural Technology Assessment and Development. Jl. Tentara Pelajar No. 10, Bogor 16124, West Java, Indonesia \\ ${ }^{4}$ Indonesian Center for Rice Research. Jl. Raya Sukamandi No. 9, Subang 41256, West Java, Indonesia \\ * All authors had been contributed equally
}

Manuscript received: 18 October 2019. Revision accepted: 1 December 2019.

\begin{abstract}
Subekti NA, Sembiring H, Erythrina, Nugraha D, Priatmojo B, Nafisah. 2020. Yield of different rice cultivars at two levels of soil salinity under seawater intrusion in West Java, Indonesia. Biodiversitas 21: 14-20. A tendency to use saline water in rice production is rising in recent years, but the adaptation of variety under saline conditions is still questionable. The aim of the study was to evaluate the response of several rice cultivars on the growth and yield of rice under seawater intrusion in West Java. Two salt-tolerant cultivars (Inpari 34 and Inpari 35), two promising lines (PL-1 and PL-2) and two modern cultivars (Inpari 30 (Ciherang subl) and Sidenuk) were evaluated in two soil salinity levels. In each farmer's field a Randomized Complete Block Design was applied with three replications per treatment. Results showed that Sidenuk and Inpari 30 produced same yield compared to tolerant varieties and promising lines during dry season under moderate soil salinity. There were not much different among the cultivars tested in terms of plant height and tiller number as well as the biomass and harvest index. However, under high soil salinity seed germination, plant height, number of tillers per plant, above-ground biomass, spikelet number, percent of sterile florets and productivity were significantly affected. Saline tolerant varieties Inpari 34 and Inpari 35 showed their superiority compared to non-tolerant varieties. Both varieties produced $40 \%$ higher yield than Inpari 30 (Ciherang sub l) and Sidenuk.
\end{abstract}

Keywords: Rice yield, salinity tolerance, seawater intrusion

\section{INTRODUCTION}

North coastline of Java is one of the production centers rice and food crops on the island of Java, with a length of around 1,316 km. About 29\% of rice-growing areas are within $10 \mathrm{~km}$ from the sea (ACIAR 2018). There was around 540,000 ha of rice fields in this region affected by seawater intrusion with average yield on dry season of 0.65 $\mathrm{t} \mathrm{ha}^{-1}$ lower than wet season (Statistics Indonesia 2017). However, under irrigated conditions, the yield potential is higher in the dry season (ACIAR 2018), highlighting the potential to increase yields in coastal areas. Salinization could be associated with the over-exploitation of groundwater due to the demand induced by increased urbanization, or by industry and agriculture. The overextraction of groundwater can result in the lowering of the normal water-bearing stratum levels, leading to the intrusion of seawater especially during the dry season. While the water discharge in the mainland began to decrease, eventually the seawater infiltrated through the canals, streams, and swamps.

The water obtained from the well not all fresh due to the canals and rivers are already mixed with saltwater. Under these conditions when groundwater of high salinity must be used, salinity becomes a major constraint to obtaining satisfactory crop yields. This has an impact on paddy fields bordering the coast, as it will be contaminated with seawater through intrusion (Erfandi and Rachman 2011). If this intrusion of seawater penetrates the land and enters the paddy field, the salinity of the land will increase beyond the critical limits (Forster et al. 2011). Increased salinity can lead to clogging of soil and soil pores tending to become solid (Barus et al. 2015). The blockage process can occur due to the dispersion of soil particles by high $\mathrm{Na}$ content. In addition, high salt levels potentially disturb the roots in nutrient uptake and damage the soil structure (Reddy et al. 2017). Research shows that coastal areas, soil salinity range from ECe $2 \mathrm{dS} \mathrm{m}^{-1}$ to $18 \mathrm{dS} \mathrm{m}^{-1}$ during the dry season ( $\mathrm{Li}$ and $\mathrm{Xu} 2007)$ while ideal rice tolerance range at planting time is ECe value less than $4 \mathrm{dS} \mathrm{m}^{-1}$ (FAO 2005). Farmers business by way of pumping was not maximal because the flow of the river is very minimal and the water is salty. This has an impact on land-use change, in which farmers initially use land for paddy rice to transform into salt-making or fishing ponds or into abandoned land. Thus, it is crucial to develop high yielding, salt-tolerant rice varieties as a mean of expanding agriculture into the regions affected by salinity (Rumanti et al. 2018).

Due to the increasing trend of population, food requirements are increasing rapidly, and it is necessary to increase crop production. The adoption of salt-tolerant rice 
is crucial to maintain sustainability of national rice production. Several promising salt-tolerant rice breeding lines have been developed and showed adaptability to saltaffected areas in the lowland coastal areas. Through national rice consortium, Inpari 34 and Inpari 35, two salinity tolerant rice varieties were released in 2014. These two varieties were more tolerant of salinity stress at seedling stage with Electrical Conductivity (EC) of $12 \mathrm{dS}$ $\mathrm{m}^{-1}$ (Hairmansis et al. 2017). These rice varietal development efforts could be able to address the future challenges of rice production in coastal deltas of Indonesia. Based on the above background, the objective of the study was to evaluate the response of several rice cultivars (tolerant and non-tolerant cultivars for saline soils) at moderate and high levels of soil salinity under seawater intrusion in West Java.

\section{MATERIALS AND METHODS}

\section{Study area}

Salinity level in rice-growing areas of Indramayu District, West Java Province has been analyzed using geographical information systems. Of the approximately 112,000 ha of paddy fields in Indramayu Regency, 16\% have high to very high soil salinity, $36 \%$ have moderate salinity and the remaining $48 \%$ are low salinity levels (ACIAR 2018). In Indramayu, 65,150 ha of rice land lies within $5-10 \mathrm{~km}$ of the coast, the majority of which is considered prone to salinity levels that substantially affect rice growth and yield (Erfandi and Rachman 2011). Based on spatial map of salinity levels, the experiments were conducted at Kertawinangun village, Kandanghaur subdistrict, Indramayu during the dry season on August to November 2018. Kertawinangun village is geographically located in latitude $98.74850 \mathrm{~N}$ and longitude $3.75150 \mathrm{E}$ and $1.5 \mathrm{~m}$ altitude. Cropping system in the region is dominantly rice-rice. Farmers usually use rice varieties Inpari 30 and Sidenuk for both wet and dry seasons. Both varieties are including the top ten most grown rice varieties in Indonesia.

\section{Procedures}

Soil sampling and analysis

A composite soil sample was collected in zigzag manner using an auger for digging to a depth of $20 \mathrm{~cm}$ before the start of the experiment. Soil samples were collected in two locations at Kertawinangun village which represent moderate and high levels of soil salinity. Soil samples were analyzed at Indonesian Soil Research Institute Laboratory, IAARD before rice sowing. They were air-dried, crushed and sieved through a 2-mm sieve and analyzed for their physicochemical properties (Table 1). Based on particle size distribution, soil texture was classified as heavy textured soil. Electrical conductivity (EC) and $\mathrm{pH}$ are measured in soil and water extracts 1: 5 . The value of EC 1: 5 for saline land is represented as medium and high, each of which was 1.728 and $2.660 \mathrm{dSm}$ ${ }^{1}$, respectively. Soil ECe relates more closely to the soluble salt concentration of the soil solution and hence is more related to plant response across soils of different texture than EC1: 5, which is a measure of total soluble salts per gram of soil. Therefore ECe is usually used to classify soils into low, medium, and high levels of soil salinity (McLeod et al. 2010). The ECe value for saline land was 7.23 and $10.51 \mathrm{dSm}^{-1}$ classified as moderately and strongly saline, respectively (FAO 2005).

\section{Laboratory experiment}

Rice seeds of Inpari-34, Inpari-35, Promising line (PL)1, PL-2, Inpari 30, and Sidenuk were obtained from Indonesian Center Rice Research (ICRR) Sukamandi, West Java. Sterilized seeds of six cultivars were imbibed in distilled water for $36 \mathrm{~h}$ and followed by air-dried with tissue paper. These genotypes were tested in real saltaffected areas. Soil was collected from moderate and high levels of soil salinity from study area. The soil was airdried for 10 days and then sieved through a $2 \mathrm{~mm}$ sieve. Ten sterilized seeds of each cultivar were allowed to grow on soil in plastic trays $(40 \mathrm{~cm} \times 27 \mathrm{~cm} \mathrm{x} 5 \mathrm{~cm})$. Each plastic tray was irrigated at regular intervals with irrigation water from the field. All plastic trays were placed in room temperature and arranged in a completely randomized design with three replications for each cultivar. Daily observation and counting of the number of seeds that were germinated were done up to twenty-one days. Observation of salt injury was used Modified Standard Evaluation Score of visual salt injury at seedling stage (Gregorio et al. 1997). Seeds were considered germinated with at least $2 \mathrm{~mm}$ radicle emergence from the seed coat. Germination percentage (GP) was calculated according to (Kandil et al. 2012).

$$
\text { GP }=\frac{\text { Number of germinated seeds }}{\text { Total number of seeds sown }}
$$

\begin{tabular}{|c|c|c|}
\hline \multirow{2}{*}{ Property } & \multicolumn{2}{|c|}{ Soil Salinity level } \\
\hline & Moderate & High \\
\hline \multicolumn{3}{|l|}{ Particle size distribution [\%]: } \\
\hline Clay & 75.5 & 77.3 \\
\hline Silt & 21.8 & 21.9 \\
\hline Sand & 0.7 & 0.8 \\
\hline Organic matter $\left[\mathrm{g} \mathrm{kg}^{-1}\right]$ & 2.27 & 1.04 \\
\hline Total-N (\%) & 0.15 & 0.80 \\
\hline $\mathrm{C} / \mathrm{N}$ ratio & 15 & 13 \\
\hline \multicolumn{3}{|l|}{$\mathrm{EC}$ and $\mathrm{pH}:$} \\
\hline EC $\left(\mathrm{dSm}^{-1}\right)$ [Soil paste extract 1: 5] & 1.728 & 2.660 \\
\hline $\operatorname{ECe}\left(\mathrm{dSm}^{-1}\right)^{*}$ & 7.23 & 10.51 \\
\hline pH [Soil suspension 1: 5] & 6.0 & 6.9 \\
\hline \multicolumn{3}{|l|}{ Exchangeable cations, CEC and ESP } \\
\hline $\mathrm{Na}^{+}\left(\mathrm{cmol} \mathrm{kg}^{-1}\right)$ & 7.31 & 13.43 \\
\hline $\mathrm{K}^{+}\left(\mathrm{cmol} \mathrm{kg}^{-1}\right)$ & 1.54 & 2.76 \\
\hline $\mathrm{Ca}^{2+}\left(\mathrm{cmol} \mathrm{kg}^{-1}\right)$ & 12.11 & 7.11 \\
\hline $\mathrm{Mg}^{2+}\left(\mathrm{cmol} \mathrm{kg}^{-1}\right)$ & 15.00 & 14.07 \\
\hline $\left.\mathrm{CEC}(\mathrm{cmol} \mathrm{kg})^{-1}\right)$ & 25.63 & 21.70 \\
\hline ESP & 21.70 & 61.89 \\
\hline
\end{tabular}

Table 1. Physical and chemical properties of studied soil, Indramayu, West Java, Indonesia, DS 2018 


\section{Field experiments}

The experiment was laid out in two farmers' fields, one field had high saline conditions and the other field had moderate saline conditions. In each farmers' field a Randomized Complete Block Design was applied with three replications per treatment. Six rice genotypes were used in this study, i.e., (1) Inpari-34 (BR41xIR61920-3B22-2), (2) Inpari-35 (IR10206-29-212xSUAKOKO), (3) PL-1, (4) PL-2, (5) Inpari-30 (Ciherang subl), and (6) Sidenuk (Diah Suci variety is irradiated by gamma rays). Inpari 30 and Sidenuk are the modern rice variety used by farmers while Inpari-34 and Inpari-35 were the tolerant variety for saline soils (Hairmansis et al. 2017). Two genotypes PL-1 and PL-2 were promising lines to salinity. Each of them was conducted under medium and high levels of soil salinity.

Standard plant-population density was $25 \mathrm{~cm}$ x $25 \mathrm{~cm}$ hill spacing with 2-3 seedlings hill $^{-1}$ and 30 days old seedling with a plot size of $5 \mathrm{~m} \times 6 \mathrm{~m}$. Recommended fertilizer package as best fertilizer management practices (Sembiring et al. data not shown) consisted of inorganic fertilizers of NPK (15: 15: 15) $100 \mathrm{~kg} \mathrm{ha}^{-1}$, triple superphosphate $\left(36 \% \mathrm{P}_{2} \mathrm{O}_{5}\right) 100 \mathrm{~kg} \mathrm{ha}^{-1}$, ammonium sulfate $(21 \% \mathrm{~N}, 24 \% \mathrm{~S}) 100 \mathrm{~kg} \mathrm{ha}^{-1}$, gypsum $(23.3 \% \mathrm{Ca}, 17 \% \mathrm{~S})$ $50 \mathrm{~kg} \mathrm{ha}^{-1}$, plus organic fertilizer $1 \mathrm{t} \mathrm{ha}^{-1}$ or equivalent to $135.5 \mathrm{~kg} \mathrm{~N}, 52 \mathrm{~kg} \mathrm{P}_{2} \mathrm{O}_{5}, 16 \mathrm{~kg} \mathrm{~K} 2 \mathrm{O}, 33 \mathrm{~kg} \mathrm{~S}$ and $11.5 \mathrm{~kg}$ $\mathrm{Ca} \mathrm{ha}^{-1}$. Gypsum and organic fertilizer were applied 7 days before rice transplanting by incorporating them into the soil. All inorganic fertilizers of NPK, triple superphosphate, and ammonium sulfate were applied 7 days after planting. Two-split urea-N fertilization was applied at 24 and 35 days after planting.

Plant height was measured two times at 50 days after transplanting (DAT), and at physiological maturity (about 5 days before harvesting). Physiological maturity is visually identified when grain on the lower portion of secondary and tertiary panicles reaches the hard dough stage and begins to lose its green color. Plant biomass at physiological maturity was done by collection of $0.5 \mathrm{~m}^{2}$, made sub-sample and dried until constant weight at $60^{\circ} \mathrm{C}$. For yield component, harvested plants at $0.5 \mathrm{~m}^{2}$ area at physiological maturity were observed for the number of panicles, filled and unfilled spikelet, 1000 grain weight, and grain moisture content. Grain yield was measured from one $9 \mathrm{~m}^{2}$ sampling area per plot at harvest. Samples were oven-dried and moisture readings are taken and crop cut weights were converted to tons per ha at $14 \%$ of moisture content. Yield reduction was calculated based on grain yield under moderate level of soil salinity as a control to high level of soil salinity as used by Rad et al. (2012).

\section{Data analysis}

Data of both experiments were analyzed using CROPSTAT version 7.2.3. Means of treatment data were compared using Duncan's Multiple-Range Test (DMRT) at $\mathrm{P}<0.05$.

\section{RESULTS AND DISCUSSION}

\section{Germination percentages and salt injury score}

The findings showed clearly that rice varieties responded significantly to different salinity levels during germination stage (Table 2). Under moderate soil salinity seeds of Inpari 34 and Inpari 35 have been shown significantly higher germination percentages than other cultivar tested. Both varieties showed normal growth with no leaf symptoms of salt injury. Inpari-34 and Inpari-35 were more tolerant of salinity stress at seedling stage as found by Hairmansis et al. (2017). It was observed that there is no significant difference in germination percentage between cultivar PL-1, PL-2, Inpari 30 and Sidenuk. All seedlings cultivar showed nearly normal growth, but leaf tips or few leaves whitish and rolled.

The germination of the rice seeds decreased drastically under high salinity soil due to the increased salt concentrations (Ul-Arif et al. 2018). However, under high soil salinity, Inpari 34 and Inpari 35 has been shown their superiority compared to Inpari 30 and Sidenuk. Inpari 34, Inpari 35, PL-1 and PL-2 showed no significant difference and have significantly higher germination percentages than Inpari 30 and Sidenuk even though growth of seedlings severely retarded, most leaves were rolled, barren spots and only a few were elongating. The extent and frequency of bare spots are often an indication of the concentration of salts in the soil (Reddy et al. 2017). The germination percentages of Sidenuk variety were found to be the least in magnitude, almost all plants dead or dying.

Table 2. Germination percentages (\%) and salt injury score of rice genotypes under moderate and high level of soil salinity

\begin{tabular}{llll} 
Genotype & $\begin{array}{l}\text { Germination } \\
\text { percentages } \\
(\%)\end{array}$ & $\begin{array}{l}\text { Salt } \\
\text { injury } \\
\text { score }^{*}\end{array}$ & Observation \\
\hline
\end{tabular}

$\begin{array}{lccl}\text { Moderate level soil salinity } & & \\ \text { Inpari-34 } & 90.0 \mathrm{a} & 1 & \text { Normal growth, no leaf } \\ \text { Inpari-35 } & 96.7 \mathrm{a} & 1 & \text { symptoms } \\ \text { PL-1 } & 76.7 \mathrm{~b} & 3 & \text { Nearly normal growth, but } \\ \text { PL-2 } & 76.7 \mathrm{~b} & 3 & \text { leaf tips or few leaves } \\ \text { Inpari-30 } & 73.3 \mathrm{~b} & 3 & \text { whitish and rolled } \\ \text { Sidenuk } & 70.0 \mathrm{~b} & 3 & \end{array}$

\section{High-level soil salinity}

\begin{tabular}{|c|c|c|c|}
\hline \\
\hline Inpari-34 & $40.0 \mathrm{a}$ & 5 & Growth severely retarded \\
\hline Inpari-35 & $46.7 \mathrm{a}$ & 5 & most leaves rolled, only a \\
\hline PL-1 & $36.7 \mathrm{a}$ & 5 & few are elongating \\
\hline PL-2 & $40.0 \mathrm{a}$ & 5 & \\
\hline Inpari-30 & $26.7 \mathrm{ab}$ & 7 & $\begin{array}{l}\text { Complete cessation of } \\
\text { growth; most leaves dry; } \\
\text { some plants dying }\end{array}$ \\
\hline Sidenuk & $6.7 \mathrm{~b}$ & 9 & $\begin{array}{l}\text { Almost all plants dead or } \\
\text { dying }\end{array}$ \\
\hline
\end{tabular}

Note: ${ }^{*}$ ) Modified Standard Evaluation Score (SES) of visual salt injury at seedling stage. In a column, means followed by the same letter are not significantly different at the $5 \%$ level by Duncan's multiple range test. 


\section{Morphological characteristics of rice genotypes}

Plant height and tiller number varied greatly among cultivars under moderate and high levels of soil salinity (Table 3). They are statistically different. At each level of soil salinity, the difference in plant height especially, maybe due to differences in genetic factors that control this trait in these varieties. Under moderate soil salinity, Sidenuk variety showed the highest plant height and tiller number at physiological maturity. However, the response of the different cultivars has been more significant under high level of soil salinity. Sidenuk and Inpari 30, both nontolerant varieties to soil salinity, showed the lowest plant height and tiller number compared to tolerant rice variety Inpari 34 and Inpari 35. Compared to that in moderate soil salinity, the average plant height of Inpari 30 and Sidenuk at high soil salinity decreased by $31 \%$ while Inpari 34 and Inpari 35 decreased by 24 . Responses tiller number is clearly different between moderate and high salinity levels. The average tillers number of Inpari 30 and Sidenuk which decreased by $69 \%$ while Inpari 34 and Inpari 35 only decreased by 50\%. Alam (2004) stated that their differences have resulted from plant root competition of nutrients and water. Doberman and Fairhust (2000) stated that plant root development and tiller number are affected by plant ability to absorb nutrient, especially phosphate. The low productivity of saline soils can be attributed not only to their toxicity due to the salt or to the damage caused by excessive amounts of soluble salts, but also to low soil fertility. The fertility problems are usually evidenced by a lack of organic matter and of available mineral nutrients, especially N and P (Subardja et al. 2016). These soils are also usually characterized by a reduction in the activities of some key soil enzymes, such as urease and phosphatase (Liang et al. 2003; Widawati 2014), which are associated with biological transformations and the bioavailability of $\mathrm{N}$ and $\mathrm{P}$.
No significant effect also showed among cultivars on the above-ground biomass under moderate salinity. Moderate salinity, however, particularly if it tends to be uniform throughout the field, can often go undetected because it causes no apparent injuries other than restricted growth. Leaves of plants growing in salt infested areas may be smaller and darker blue-green in color than the normal leaves (Kalhori et al. 2018). Increased soil salinity adversely influences plant growth, leading to significant reductions in plant height, tiller number, and above-ground biomass. The differences were statistically significant due to inter cultivar (genetic) differences. Genotypic variability in salinity tolerance in rice is mainly due to differing abilities in excluding $\mathrm{Na}+$ from the shoot. Higher $\mathrm{Na}^{+}$ exclusion and increase of $\mathrm{K}^{+}$absorption help tolerant plants to maintain low $\mathrm{Na}^{+} / \mathrm{K}^{+}$in the shoot, conserving photosynthetic functioning and tissue growth (Radanielson et al. 2018). Radanielson et al. (2017) described crop responses to salinity, accounting for the variability of responses in biomass production processes (namely transpiration and photosynthesis) among different rice varieties. Salinity has three potential effects on plant growth generally through (i) lowering of the water potential, (ii) direct toxicity caused by excessive uptake of salt-forming elements such as sodium and (iii) interference with the uptake of essential nutrients especially potassium (Flowers and Flowers 2005). In saline conditions, plant growth and development are hampered due to excessive accumulation of $\mathrm{Na}$ and $\mathrm{Cl}$ in the cytoplasm, causing changes in the cell metabolism and enzyme activity. These conditions also resulted in partial dehydration of cells and loss of cell turgor due to reduced water potential in the cell (Acosta-Motos et al. 2017). In the case of high salt content of rice plants will be disrupted and died, especially during the vegetative period.

Table 3. Some morphological characteristics of rice genotypes under moderate and high levels of soil salinity, Indramayu, West Java, DS 2018

\begin{tabular}{|c|c|c|c|c|c|}
\hline \multirow[b]{2}{*}{ Genotype } & \multicolumn{2}{|c|}{ Plant height $(\mathbf{c m})$} & \multicolumn{2}{|c|}{ Tiller Number } & \multirow{2}{*}{$\begin{array}{l}\text { Above ground } \\
\text { biomass } \\
\left(\mathrm{g} \mathrm{0.5} \mathrm{m}^{-2}\right) \\
\end{array}$} \\
\hline & 50 DAT & $\begin{array}{l}\text { At physiological } \\
\text { maturity }\end{array}$ & 50 DAT & $\begin{array}{l}\text { At physiological } \\
\text { maturity }\end{array}$ & \\
\hline
\end{tabular}

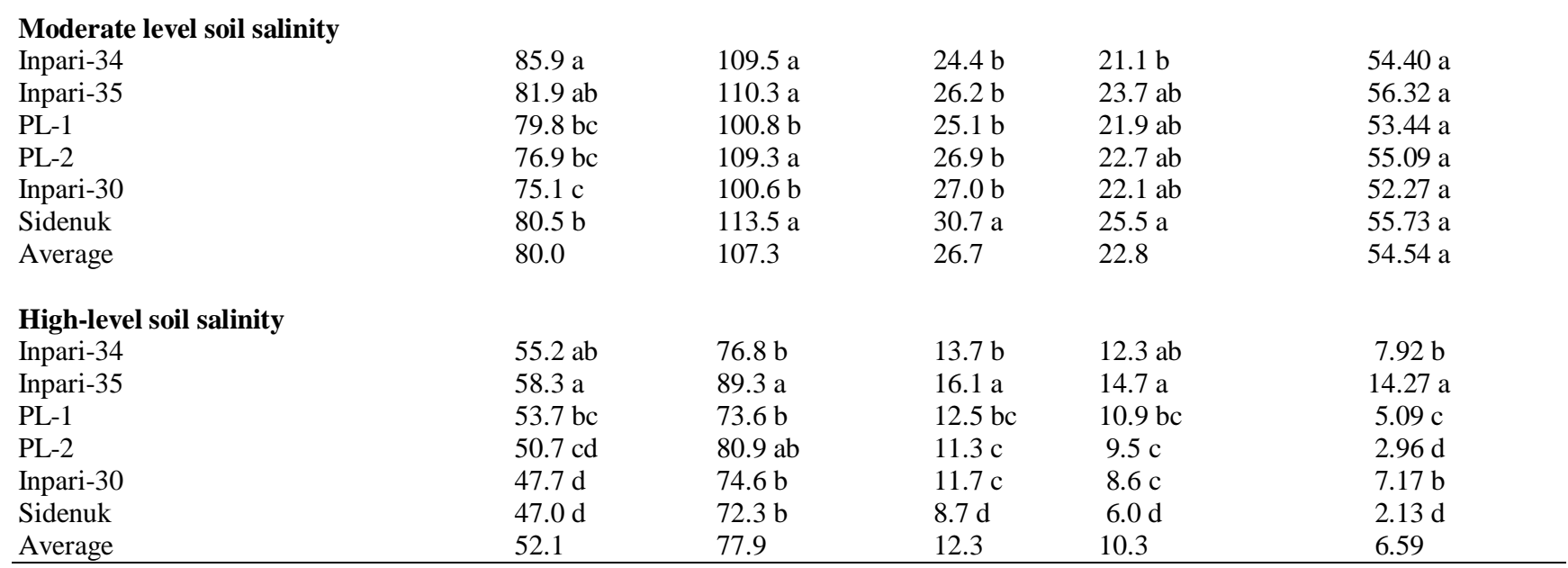

Note: In a column, means followed by the same letter are not significantly different at the $5 \%$ level by Duncan's multiple range tests 


\section{Yield and yield components}

Under moderate level of soil salinity, yield components of different rice genotypes especially number of empty grain were not much different (Table 4). However, the result of mean comparison of yield components showed that the influence of soil salinity level. Under high level of soil salinity panicle number, number of seeds per panicle, and weight of 1000 seeds were decrease while number of empty grain was increase compared to moderate soil salinity. High influence of soil salinity on the yield components was reported by researchers ( $\operatorname{Rad}$ et al. 2012; Aref 2013; Pradheeban 2017). Sidenuk and Inpari 30 both non-tolerant modern varieties showed significantly affected by high soil salinity. The rice crops are drying and impacting crop failure. Sidenuk variety produced no yield at all at high soil salinity levels.

Results showed a considerable sensitivity of harvest index to soil salinity. Plant harvest index, the ratio of grain weight to total plant weight, is an important trait associated with the increases in crop yields. Harvest index reflects the partitioning of photosynthate between the grains and the vegetative plant and improvements in harvest index emphasize the importance of carbon allocation in grain production (Kemanian et al. 2007).

Under moderate soil salinity level, effects of different cultivars on rice yield were not statistically significant. Under high salt stress conditions, most of the crop plants are susceptible and unable to survive. The highest number of grain yield was produced by Inpari 35, (5.899 $\left.\mathrm{t} \mathrm{ha}^{-1}\right)$ followed by Inpari $34\left(5.426 \mathrm{t} \mathrm{ha}^{-1}\right)$. Other cultivars tested were susceptible under high level of soil salinity, represented 93 to $100 \%$ yield reduction for PL-1, PL-2, Inpari 30 and Sidenuk (Table 3). Salt stress has two primary harmful effects; osmotic and ionic stress. Osmotic stress leads to reduction of water uptake by root, and accumulation and toxicity of specific ions caused ionic stress. Both ionic and osmotic stresses lead to reduced growth rates and eventually to plant death (Kalhori et al. 2018).

\section{Discussion}

The results in Table 2 showed that germination percentages decreased significantly due to the increased soil salinity level. Kalhori et al. (2018) observed that the seeds required longer time to germinate, and the number of germinated seeds was also reduced at higher salt concentration. Although some crops seem to tolerate salinity during seed germination as well as during later growth stages, germination failures are most commonly responsible for poor and spotty stands and bare spots in otherwise cultivated fields (Kalhori et al. 2018). Frequently, this is not the result of crops being especially sensitive during germination, but rather is caused by exceptionally high salt concentration in the shallow surface zone where seeds are planted. These high salt concentrations result from the salt that is left behind as the upward moving water is evaporated near the soil surface (Lu 2019). Tolerance to salinity at germination is usually not of much significance since in most rice-growing areas rice, is grown in a nursery in good soil and then transplanted when the seedlings are 25 to 35 days old.

The results showed that under high level of soil salinity level, panicle number, number of seed per panicle, and weight of 1000 seeds did decrease while number of empty grain did increase as compared to that at moderate soil salinity level. Rad et al. (2012) showed that along with the increasing salinity level, the inflorescence was progressively delayed and the number of sterile spikelets increased. Salt stress caused both osmotic and ionic stresses on rice plant which result in plant growth reduction and premature leaf senescence (Acosta-Motos et al. 2017; García-Morales et al. 2018).

Table 4. Yield components of rice genotypes under medium and high level of soil salinity, Indramayu, West Java, DS 2018

\begin{tabular}{|c|c|c|c|c|c|}
\hline Genotype & $\begin{array}{c}\text { Panicle } \\
\text { number } \text { hill }^{-1}\end{array}$ & $\begin{array}{c}\text { Number of seed } \\
\text { panicle }^{-1}\end{array}$ & $\begin{array}{c}\text { Empty grain } \\
(\%)\end{array}$ & $\begin{array}{c}\text { Weight of 1,000 } \\
\text { grain (g) }\end{array}$ & $\begin{array}{c}\text { Harvest } \\
\text { index }\end{array}$ \\
\hline \multicolumn{6}{|c|}{ Moderate level soil salinity } \\
\hline Inpari-34 & $21.1 \mathrm{~b}$ & $123.3 \mathrm{~b}$ & $16.5 \mathrm{a}$ & $24.7 \mathrm{ab}$ & $31.2 \mathrm{a}$ \\
\hline Inpari-35 & $23.7 \mathrm{ab}$ & $131.9 \mathrm{a}$ & $15.2 \mathrm{a}$ & $25.8 \mathrm{a}$ & $32.7 \mathrm{a}$ \\
\hline PL-1 & $21.9 \mathrm{ab}$ & $111.6 \mathrm{c}$ & $16.9 \mathrm{a}$ & $24.7 \mathrm{ab}$ & $31.2 \mathrm{a}$ \\
\hline PL-2 & $22.7 \mathrm{ab}$ & $107.5 \mathrm{c}$ & $17.1 \mathrm{a}$ & $23.8 \mathrm{~b}$ & $30.1 \mathrm{a}$ \\
\hline Inpari-30 & $22.1 \mathrm{ab}$ & $123.4 \mathrm{~b}$ & $15.6 \mathrm{a}$ & $25.3 \mathrm{a}$ & $34.2 \mathrm{a}$ \\
\hline Sidenuk & $25.5 \mathrm{a}$ & $119.8 \mathrm{bc}$ & $16.6 \mathrm{a}$ & $24.8 \mathrm{ab}$ & $31.6 \mathrm{a}$ \\
\hline \multicolumn{6}{|c|}{ High-level soil salinity } \\
\hline Inpari-34 & $12.3 \mathrm{ab}$ & $56.5 \mathrm{~b}$ & $26.5 \mathrm{~d}$ & $19.2 \mathrm{~b}$ & $27.4 \mathrm{~b}$ \\
\hline Inpari-35 & $14.7 \mathrm{a}$ & $73.5 \mathrm{a}$ & $25.5 \mathrm{~d}$ & $22.1 \mathrm{a}$ & $30.4 \mathrm{a}$ \\
\hline PL-1 & $10.9 \mathrm{bc}$ & $43.2 \mathrm{c}$ & $37.3 \mathrm{c}$ & $17.8 \mathrm{c}$ & $21.6 \mathrm{c}$ \\
\hline PL-2 & $9.5 \mathrm{c}$ & $39.9 \mathrm{c}$ & $42.0 \mathrm{~b}$ & $17.4 \mathrm{c}$ & $17.3 \mathrm{~d}$ \\
\hline Inpari-30 & $8.6 \mathrm{c}$ & $58.6 \mathrm{~b}$ & $33.3 \mathrm{c}$ & $18.3 \mathrm{bc}$ & $22.8 \mathrm{c}$ \\
\hline Sidenuk & $6.0 \mathrm{~d}$ & $37.1 \mathrm{c}$ & $100.0 \mathrm{a}$ & - & - \\
\hline
\end{tabular}

Note: In a column, means followed by the same letter are not significantly different at the $5 \%$ level by Duncan's multiple range test. 
Table 5. Yield and its reduction of various rice genotypes in different level of soil salinity, Indramayu, West Java, DS 2018

\begin{tabular}{lcccc}
\hline \multirow{2}{*}{ Genotype } & \multicolumn{2}{c}{ Yield $\left(\mathbf{t ~ h a}^{-\mathbf{1}}\right)$} & \multicolumn{2}{c}{$\begin{array}{c}\text { Yield reduction in high salinity level as } \\
\text { compared to moderate salinity level }\end{array}$} \\
\cline { 2 - 5 } & Moderate level soil salinity & High-level soil salinity & \multicolumn{1}{c}{ t ha $^{-\mathbf{1}}$} & 87 \\
\hline Inpari-34 & $5.426 \mathrm{a}$ & $0.693 \mathrm{~b}$ & 4.733 & 76 \\
Inpari-35 & $5.899 \mathrm{a}$ & $1.387 \mathrm{a}$ & 4.512 & 93 \\
PL-1 & $5.334 \mathrm{a}$ & $0.351 \mathrm{bcd}$ & 4.983 & 97 \\
PL-2 & $5.302 \mathrm{a}$ & $0.164 \mathrm{~cd}$ & 5.138 & 90 \\
Inpari-30 & $5.886 \mathrm{a}$ & $0.591 \mathrm{bc}$ & 5.295 & 100 \\
Sidenuk & $5.635 \mathrm{a}$ & $0 \mathrm{~d}$ & 5.635 & \\
\hline
\end{tabular}

Note: In a column, means followed by the same letter are not significantly different at the $5 \%$ level by Duncan's multiple range test

Plant adaptation to salt stress has been involving complex mechanisms and generally categorized into three main mechanisms including osmotic tolerance, ion exclusion and ion tissue tolerance (Roy 2014). Effects of salinity on rice occur at two stages, i.e., at the initial phase of plant development, the osmotic effects rapidly reduce plant growth and the second slow phase of plant response to salinity when symptoms of salinity-induced toxicity appear. At morphological levels shoot and root growth, above-and below-ground biomass production, number of tillers and spikelet and grain yield of rice are adversely affected (Riaz et al. 2019).

The present study results indicate clearly that under moderate soil salinity there was no significant difference in yield of modern rice variety Sidenuk and Inpari 30 compared to tolerant rice variety of Inpari 34 and Inpari 35. The average yield of Sidenuk and Inpari 30 varieties was $5.76 \mathrm{t} \mathrm{ha}^{-1}$ while Inpari 34 and Inpari 35 yielded $5.66 \mathrm{t} \mathrm{ha}^{-1}$. This is a clear indication that Inpari 30 and Sidenuk have broad adaptation ability under normal (no salt stress) to medium soil salinity level. Based on the area of planting, both varieties are included as top ten rice varieties in Indonesia. Inpari 30 is selected for improvement from "mega variety" Ciherang (IR18349-53-1-3-1-3/IR19661131-3-1//IR19661-131-3-1-///IR64/////IR64), a widely grown Indonesian cultivar developed from multiple variety crosses including IR64. An upgraded version of this variety carrying the submergence tolerance gene sub1 is named Inpari 30 Ciherang sub1 (Septiningsih et al. 2015; Toledo et al. 2015). The primary growth stages, i.e., tillering and panicle initiation was more sensitive to salinity. Therefore, irrigation with saline water can be used in the final stages of plant growth, i.e. panicle emergence and maturity.

Under high level of soil salinity, the average yield of Inpari 30 was only $0.6 \mathrm{t} \mathrm{ha}^{-1}$ while Sidenuk crops is drying and impacting crop failure. Inpari 34 and Inpari 35, both tolerant varieties for salinity have average yield of $1.0 \mathrm{t} \mathrm{ha}^{-1}$ compared to the average yield of Sidenuk and Inpari 30 which is only $0.3 \mathrm{t} \mathrm{ha}^{-1}$. There was a yield advantage of $70 \%$ when using tolerant varieties when planting the rice on high salinity soil. Barren spots and stunted plants may appear in Inpari 30 growing on high saline areas. The extent and frequency of bare spots is often an indication of the concentration of salts in the soil (Reddy et al. 2017). The capacity to tolerate salinity is a key factor in plant productivity (Stacy et al. 2019). The rice varietal development efforts could be able to address the future challenges of rice production in coastal deltas of Indonesia. Multiple stress tolerance traits must be considered in breeding rice for saline environments as long-term adaptability of a variety is dependent on its level of tolerance to all the stress that occurs in its growing environment.

In summary, our results implied that high level of salinity leads to reduction in germination percentage, plant height, tiller number, yield and yield components, and increase in empty grain percentage. Biomass and harvest index were negatively affected by increasing soil salinity. Inpari 30 and Sidenuk yielded non-significant different compared to tolerant salt varieties and promising lines tested under moderate level of soil salinity. Under high level of soil salinity Inpari 34 and Inpari 35 still produced $70 \%$ higher yield than Inpari 30 or Sidenuk rice variety.

\section{ACKNOWLEDGEMENTS}

We are grateful for financial support from the Indonesian Agency for Agricultural Research and Development (IAARD) and the World Bank for the Sustainable Management of Agricultural Research and Technology Dissemination (SMARTD) program.

\section{REFERENCES}

ACIAR. 2018. Assessment of management in key coastal areas of Indonesia to improve agricultural productivity and resilience to climate change. ACIAR, Canberra, Australia.

Alam MZ, Stuchbury T, Naylor REL, Rashid MA. 2004. Effect of Salinity on Growth of Some Modern Rice Cultivars. J Agron 3: 1-10.

Barus WA, Rauf A, Rosmayati, Hanum C. 2015. Improvement of salt tolerance in some varieties of rice by ascorbic acid application. Intl $\mathrm{J}$ Sci Technol Res 4 (5): 235-237

Erfandi D, Rachman A. 2011. Identification of Soil Salinity Due to Seawater Intrusion on Rice Field in the Northern Coast of Indramayu, West Java. J Trop Soils 16: 115-121

FAO. 2005. Saline Soils and Their Management. FAO, Rome.

Flowers TJ, Flowers SA. 2005. Why does salinity pose such a difficult problem for plant breeders? Agric Water Manag 78: 15-24.

Forster H, Sterzel T, Pape CA, Moneo-Lain M, Niemeyer I, Boer R, Kropp JP. 2011. Sea-level rise in Indonesia: on adaptation priorities in the agricultural sector. Reg Environ Ch 11: 893-904

García-Morales S, Gómez-Merino FC, Trejo-Téllez LI, Tavitas-Fuentes L, Hernández-Aragón, L. 2018. Osmotic stress affects growth, content of chlorophyll, abscisic acid, $\mathrm{Na}+$, and $\mathrm{K}+$, and expression of novel NAC genes in contrasting rice cultivars. Biologia Plantarum 62 (2): 307-317 
Gregorio GB, Senadhira D, Mendoza RD. 1997. Screening Rice for Salinity Tolerance. Discuss Pap Ser 22: 30 International Rice Research Institute, Manila, Philippines.

Hairmansis A, Nafisah, Jamil A. 2017. Towards Developing Salinity Tolerant Rice Adaptable for Coastal Regions in Indonesia Conference Proceedings 2nd International Conference on Sustainable Agriculture and Food Security: A Comprehensive Approach. KnE Life Sciences, pages 72-79.

Kalhori N, Ying T, Nulit R, Sahebi M, Abiri R, Atabaki N. 2018. Effect of four different salts on seed germination and morphological characteristics of Oryza sativa L. cv. MR219. Intl J Adv Res Bot 4 (1): $29-45$

Kemanian, AR, Sto“ckle CO, Huggins DR, Viega LM. 2007. A simple method to estimate harvest index in grain crops. Field Crops Res 103 (2007): 208-216.

McLeod MK, Slavich PG, Irhas Y, Moore N, Rachman A, Ali N, Iskandar T, Hunt C, Caniago C. 2010. Soil salinity in Aceh after the December 2004 Indian Ocean tsunami. Agric Water Manag 97: 605-613

Pradheeban L, Nissanka SP, Suriyagoda LDB. 2017. Influence of whole and sub soil salinity on growth, development, physiology and yield of selected rice varieties cultivated in Jaffna district, Sri Lanka. Trop Agric Res 28 (4): 389-401

Rad HE, Aref F, Rezae M. 2012. Response of Rice to Different Salinity Levels during Different Growth Stages. Res J App Sci Eng Technol 4 (17): 3040-3047

Radanielson AM, Angeles O, Li T, Ismail AM, Gaydon DS. 2017. Describing the physiological responses of different rice genotypes to salt stress using sigmoid and piecewise linear functions. Field Crops Res. 211 (172)

Radanielson, AM, Gaydon DS, Lia T, Angelesa O, Roth CH. 2018 Modeling salinity effect on rice growth and grain yield with ORYZA v3 and APSIM-Oryza. Eur J Agron 100: 44-55.

Reddy NBL, Kim BK, Yoon IS, Kim KH, Kwon TR. 2017. Salt tolerance in rice: Focus on mechanisms and approaches. Rice Sci 24 (3): 123 144

Rengasamy, 2006. Soil salinity and sodicity. In: Stevens D. (ed.), Growing Crops with Reclaimed Wastewater. CSIRO Publishing, Collingwood, Australia.

Riaz M, Arif MS, Ashraf MA, Mahmood R, Yasmeen T, Shakoor MB, Shahzad SM, Ali M, Saleem I, Arif M, Fahad S. 2019. A comprehensive review on rice responses and tolerance to salt stress.
In: Hasanuzzaman M, Fujita M, Nahar K, Biswas JK (eds). Advances in Rice Research for Abiotic Stress Tolerance. Elsevier Inc., New York.

Roy SJ, Negra SN, Tester M. 2014. Salt resistant crop plants. Curr Opin Biotechnol 26: 115-124

Rumanti IA, Hairmansis A, Nugraha Y, Nafisah, Susanto U, Wardana P, Subandiono RE, Zaini Z, Sembiring H, Khan NI, Singh RK, Johnson DE, Stuart AM, Kato Y. 2018. Development of tolerant rice varieties for stress-prone ecosystems in the coastal deltas of Indonesia. Field Crop Res 223: 750-82

Septiningsih EM, Hidayatun N, Sanchez DL, Nugraha Y, Carandang J, Pamplona AM, Collard CYC, Ismail AM, Mackill DJ. 2015. Accelerating the development of new submergence tolerant rice varieties: the case of Ciherang-Sub1 and PSB Rc18-Sub1. Euphytica 202: $259-268$

Stacy D, Nora S, Foroud A, Laurie JD. 2019. Molecular Improvement of Grain: Target Traits for a Changing World. In: Smither GW, Ferranti P. (eds). Encyclopedia of Food Security and Sustainability, Volume 2. Elsevier Inc., New York

Statistics Indonesia, 2017. Statistical Yearbook of Indonesia 2017. Statistics Indonesia, Jakarta.

Subardja VO, Anas I, Widyastuti R. 2016. Utilization of organic fertilizer to increase paddy growth and productivity using System of Rice Intensification (SRI) method in saline soil. J Degrad Mining Lands Manag 3 (2): 543-549.

Toledo AMU, Ignacio JCI, Casal C, Gonzaga ZJ, Mendioro, MS, Septiningsih EM. 2015. Development of improved Ciherang-Sub1 having tolerance to anaerobic germination conditions. Plant Breed Biotechnol 3: 77-87

Ul-Arif MT, Sayed MA, Islam MM, Siddiqui MN, Begum SN, Hossain MA. 2018. Screening of rice landraces (Oryza sativa L.) for seedling stage salinity tolerance using morpho-physiological and molecular markers. Acta Physiologiae Plantarum 40: 70

Widawati S. 2014. The effect of salinity to activity and effectivity phosphate solubilizing bacteria on growth and production of paddy. In: Pratiwi R, Nurlaely S, Maryani, Retnoaji B, Nuringtyas TR, Susandarini R (eds). Advances in Biological Science: Biological Approach for Sustainable Development of Tropical Biodiversitas for Human Prosperity. Proceeding of the International Conference on Biological Science, Faculty of Biology, Gadjah Mada University, Yogyakarta. 